\title{
INFLUENCE OF THE SPECIFIC AREA OF QUARTZ SAND ON THE CHARACTER OF AN AUTOCLAVED CALCIUM SILICATE COMPOSITE
}

\author{
VPLIV SPECIFIČNE POVRŠINE KVARČNEGA PESKA NA \\ KARAKTER KALCIJ-SILIKATNEGA KOMPOZITA, IZDELANEGA \\ V AVTOKLAVU
}

\author{
Jana Húšt'avová, Vít Černý, Rostislav Drochytka \\ Brno University of Technology, Faculty of Civil Engineering, Veveri 331/95, 60200 Brno, Czech Republic \\ Prejem rokopisa - received: 2018-07-31; sprejem za objavo - accepted for publication: 2018-09-06
}

doi:10.17222/mit.2018.168

\begin{abstract}
The physical-mechanical properties of calcium silicate composites are structure dependent. It is necessary to check the properties of the raw materials to ensure the required quality of the calcium hydro silicate microstructure. One of the decisive features is the specific surface area of the siliceous material. The particle size significantly affects the solubility during autoclaving and thus incorporating the silica into the microstructure. This paper deals with the influence of the particle size of quartz sand on the properties and structure of the composite. Two types of sand were used with three different specific surfaces. The tested values of the specific surface area of the quartz sand were $1300 \mathrm{~cm}^{2} / \mathrm{g}, 2600 \mathrm{~cm}^{2} / \mathrm{g}$ and $3600 \mathrm{~cm}^{2} / \mathrm{g}$. The sand was mixed with lime in molar ratios of calcium oxide to silicon dioxide equal to 0.73 and 1.00 . The calcium silicate composites were exposed to a hydrothermal treatment at $190^{\circ} \mathrm{C}$ for an isothermal endurance time of $(4,8$ and 16) $\mathrm{h}$. The mechanical properties were determined for the treated samples. The samples were further studied by microstructure, by X-ray diffraction analysis and by scanning electron microscopy.

Keywords: quartz sand, specific surface, tobermorite, calcium-silicate composite
\end{abstract}

Fizikalno-mehanske lastnosti kalcij-silikatnih kompozitov so odvisne od strukture. Zato je potrebno preveriti lastnosti osnovnih surovin in $s$ tem zagotoviti zahtevano kvaliteto kalcij-hidro-silikatne mikrostrukture. Pri tem je odločilna specifična površina uporabljenih silikatnih materialov. Velikost delcev pomembno vpliva na topnost med obdelavo v avtoklavu in tako vgrajevanjem silike v mikrostrukturo. V članku avtorji analizirajo vpliv velikosti delcev kvarčnega peska na lastnosti in strukturo kompozita. Uporabili so dve vrsti kvarčnega peska treh različnih specifičnih površin $1300 \mathrm{~cm}^{2} / \mathrm{g}, 2600 \mathrm{~cm}^{2} / \mathrm{g}$ in $3600 \mathrm{~cm}^{2} / \mathrm{g}$. Peske so zmešali z apnom v molarnih razmerjih $\mathrm{CaO}: \mathrm{SiO}_{2}$ je enako 0,73 in 1,00 . Kalcij-silikatne kompozitne mešanice so nato hidrotermalno obdelali $\left(4,8\right.$ in 16) h pri $190^{\circ} \mathrm{C}$. Sledila je določitev mehanskih lastnosti obdelanih vzorcev. Njihovo mikrostrukturo pa so določili z rentgensko strukturno analizo (XRD) in vrstičnim elektronskim mikroskopom (SEM).

Ključne besede: kvarčni pesek, specifična površina, Ca-Si-hidrat (tobermorit), kalcij-silikatni kompozit

\section{INTRODUCTION}

To study the influence of the specific surface of quartz sand on the properties of calcium-silicate composites, it is necessary to understand the principles of the solubility of quartz.

\subsection{Solubility of quartz}

Quartz is considered to be one of the less-soluble minerals, ${ }^{1}$ and is the main crystalline form of silica dioxide contained in the Earth's crust. ${ }^{2,3}$ The problems of the solubility of quartz have been examined and explained for several decades. Many researches on the solubility of quartz have been made, at the temperature of $25{ }^{\circ} \mathrm{C}$ and atmospheric pressure and at high temperatures and high pressure. ${ }^{2,4,5}$ Alexander et al. explain in their paper the formation of a solution during the dissolution of silica dioxide. It was found that monosilicic

*Corresponding author e-mail

hustavova.j@fce.vutbr.cz acid is present in the solution. This acid is formed through breaking silicates by $\mathrm{OH}^{-}$ions from the molecules of water. ${ }^{3,4}$ The solubility of silica dioxide $\left(\mathrm{SiO}_{2}\right)$ increases in the alkali environment at a $\mathrm{pH}$ value over 9.14. Hence, the solubility of quartz is dependent on the $\mathrm{pH}$ value of the solution and it dissolves better at extreme values of $\mathrm{pH}$. On the other hand, at neutral $\mathrm{pH}$ it dissolves less. ${ }^{3-5}$ This dependency is ascribed to the change of the specific surface of the quartz grain. ${ }^{5}$ The solubility of quartz in an alkali environment is defined by Equation (1)

$$
\mathrm{SiO}_{2}+2 \mathrm{H}_{2} \mathrm{O} \rightleftharpoons \mathrm{H}_{4} \mathrm{SiO}_{4}^{-}+\mathrm{H}^{+}
$$

The solubility of quartz is further influenced by the size and the shape of the grains. Spherical grains have a higher degree of solubility. As regards the size of spherical grains, the degree of solubility considerably increases for a grain size $<0.1 \mu \mathrm{m}$. If the grain size is over $0.1 \mu \mathrm{m}$, the grain will hydrate and its volume will grow. Thus, this is the critical limit of the solubility of spherical grains of quartz. Porous concave grains can have a 
worse solubility. In the pores of the grains, newly precipitated quartz may grow and slow down the solubility of the whole grain. ${ }^{3,6}$ In general, it is true, that the higher the specific surface of quartz, the higher the area that can be used for the dissolution of the grains. This means that the rate of dissolubility will be higher with an increasing specific surface. A further factor with considerable influence is whether the quartz is crystalline or amorphous. In general, it can be said that the degree of solubility grows with the increasing activity of the quartz..$^{3,7}$

\subsection{Reaction of quartz, with lime}

The reaction of quartz and calcium hydroxide for the commercial production of calcium silicate products is ensured by means of a hydrothermal treatment. During the hydrothermal treatment, the silicic and calcic components react with the water and new calcium-silicate products are formed (CSH). The CSH phase is a binder in the calcium-silicate composite. The non-reacted grains of quartz (aggregate) are connected with the newly formed $\mathrm{CSH}$ phase. This ensures that the required physical-mechanical properties of the composite material are achieved. In practise, the hydrothermal treatment of calcium-silicate products is carried out at the temperatures of steam between $150{ }^{\circ} \mathrm{C}$ to $220{ }^{\circ} \mathrm{C}$, pressure of vapour $0.8-1.6 \mathrm{MPa}$ and hardening for between $3 \mathrm{~h}$ and 10 h. ${ }^{6,9,10}$

\subsection{Influence of quartz solubility on the formation of tobermorite}

Tobermorite $\left(5 \mathrm{CaO} \cdot 6 \mathrm{SiO}_{2} \cdot 5 \mathrm{H}_{2} \mathrm{O}\right)$ is a hydrate of calcium silicate produced through hydrothermal synthesis. The group of tobermorites is characterized from the point of view of various types, like $0.9 \mathrm{~nm}$ (riversideite), $1.1 \mathrm{~nm}$ (tobermorite) and 1,4 $\mathrm{nm}$ (plombierite). These are dependent on the number of water molecules and differ in terms of d-spacing in XRD. ${ }^{11}$ The $1,1 \mathrm{~nm}$ tobermorite is the main composite of autoclaved calcium-silicate composite materials like calcium-sand bricks, autoclaved aerated concrete and other similar building materials. ${ }^{11,12,13}$

Kikuma et al. deal in their research with the influence of quartz on the hydrothermal synthesis of tobermorite. They found that the solubility of quartz was, to a certain extent, influenced by the size of the particles in the initial mixes. ${ }^{10}$ Hence, the size of the quartz grains has an impact on the formation of tobermorite. Some authors agree that finer grains of quartz facilitate the easier formation of crystalline tobermorite. ${ }^{7,8}$ However, as published in Isu et al. the reaction with coarser quartz gives rise to stronger and larger lamellas of tobermorite, while samples with finer quartz resulted in tobermorite with smaller dimensions. ${ }^{14}$ To make it possible to synthetize $1,1 \mathrm{~nm}$ tobermorite, it is necessary that the size of the quartz grains source is smaller than $0.08 \mathrm{~mm} .{ }^{6}$ The formation of tobermorite is also influenced by the water ratio. As the water cement ratio increases, the solubility of quartz is almost unchanged, but the occurrence of tobermorite grows. ${ }^{10}$ Another important factor of tobermorite formation is the molar proportion of calcium oxide and silicon dioxide (C/S). Many resources state various limits of the $\mathrm{C} / \mathrm{S}$ value for the formation of tobermorite. In most cases they agree on a value of $\mathrm{C} / \mathrm{S}$ from 0.63 to 1.0 . At a higher molar proportion of $\mathrm{C} / \mathrm{S}$ xonotlite may form, which is undesirable. The formation of xonotlite reduces the physical-mechanical properties of the calcium silicate composite. Xonotlite is often found in the form of long fibres. ${ }^{15}$

The purpose of this paper is basic research on the influence of a specific surface of sand on the formation of reaction products for the technology of autoclaved, aerated concrete.

\section{MATERIALS AND METHODS}

The grinding of quartz sand constitutes a high production cost in the technology of manufacturing calcium silicate composites. For this reason, it is advisable to study the influence of size reduction on the properties of the composite material and find the optimal conditions, which is the focus of this paper. The aim was to determine the influence of the finer grinding of sand on the quality of the product. The main focus was on the influence of the value of the specific surface of quartz sand on the formation of tobermorite. Two kinds of quartz sand with three different values of specific surface were studied. The selected values of the specific surface were $1100 \mathrm{~cm}^{2} / \mathrm{g}, 2300 \mathrm{~cm}^{2} / \mathrm{g}$ and $3500 \mathrm{~cm}^{2} / \mathrm{g}$, with a tolerance of $\pm 200 \mathrm{~cm}^{2} / \mathrm{g}$. To ensure sufficient solubility and hence the reactivity of silicon dioxide in sand, the selected temperature of the hydrothermal treatment was $190{ }^{\circ} \mathrm{C}$. This is the temperature above the limit of solubility for crystalline $\mathrm{SiO}_{2}$. The composition of the input materials for the samples was selected so that the required value of the molar proportion $\mathrm{C} / \mathrm{S}$ was achieved. Based on a literature search, the values of the molar proportion of C/S were 0.73 and 1.00. These are the limit values for the formation of tobermorite.

\subsection{Chemical composition of the input materials}

First of all the input materials were selected so that sufficient amounts of $\mathrm{CaO}$ and $\mathrm{SiO}_{2}$ in the mix were ensured. Unslaked lime was selected as a carrier of $\mathrm{CaO}$. Two kinds of quartz sand were selected as a source of $\mathrm{SiO}_{2}$. The chemical compositions of the sands are stated in Table 1. The lime contained 95.62 w/\% of $\mathrm{CaO}$.

Table 1: Chemical composition of the sands (w/\%)

\begin{tabular}{|c|c|c|c|c|c|}
\hline & $\mathrm{SiO}_{2}$ & $\mathrm{Al}_{2} \mathrm{O}_{3}$ & $\mathrm{Fe}_{2} \mathrm{O}_{3}$ & $\mathrm{~K}_{2} \mathrm{O}$ & $\mathrm{Na}_{2} \mathrm{O}$ \\
\hline Quartz sand 1 & 94.91 & 1.89 & 0.90 & 0.87 & 0.30 \\
\hline Quartz sand 2 & 95.16 & 1.52 & 1.21 & 0.71 & 0.23 \\
\hline
\end{tabular}


Based on this input analysis, mix-designs with the required $\mathrm{C} / \mathrm{S}$ molar proportions were calculated. The method of sample preparation is stated further in the paper.

\subsection{Reactivity of lime}

This parameter is the basic characteristic observed for construction lime used for the production of aerated concrete. The test is based on measuring the increase of the temperature during the slaking of lime. The observed parameter is the time in which the mix of lime and water reaches the temperature of $60{ }^{\circ} \mathrm{C}$. The value recommended for the manufacture of aerated concrete is between 6 min and $15 \mathrm{~min}$.

\section{Particle size distribution curve - QS1}

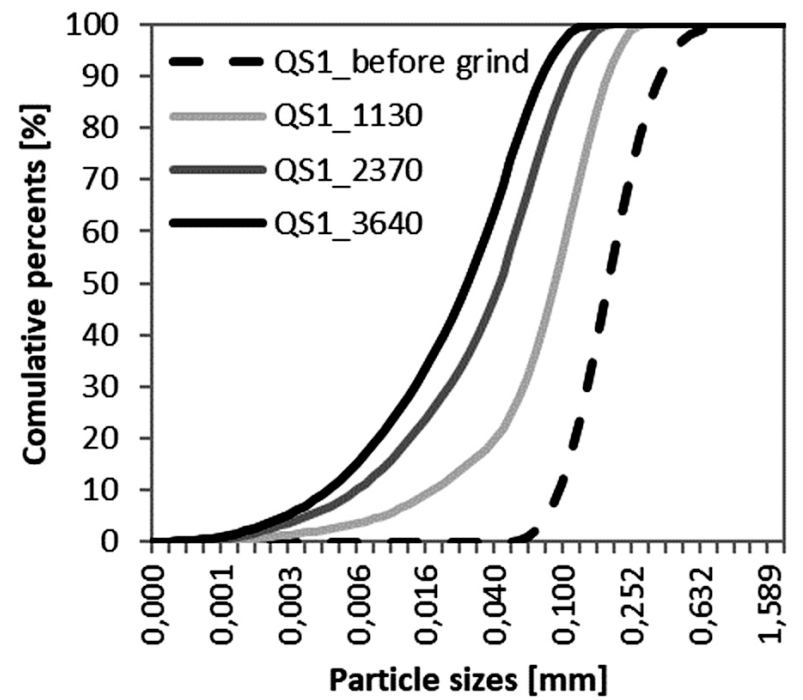

Particle size distribution curve QS2

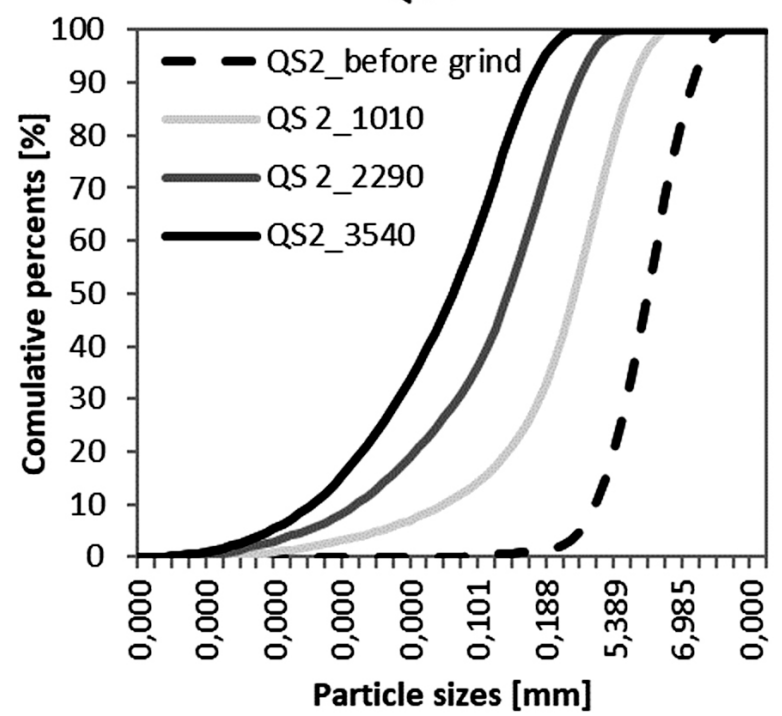

Figure 1: Granulometric curves of sand 1 (QS1) and sand 2 (QS2)
The determined value of the reactivity was $359 \mathrm{~s}$, which means $5 \mathrm{~min}$ and $59 \mathrm{~s}$. The specification of such lime in accordance with EN $459-1^{16}$ is CL 90 - Q (R5). The maximum determined hydration temperature was $77.55{ }^{\circ} \mathrm{C}$ at the time $2216 \mathrm{~s}$, which means $36 \mathrm{~min}$ and $56 \mathrm{~s}$.

\subsection{Basic characteristics of the sands}

The next step was the determination of the values of the bulk density of sands. Then, the sands were ground in a ball grinder to the three required values of the specific surface. The values of the specific surface of the sands are stated in Table 2. Table 2 also gives the time of grinding. The ground sand was then sifted through a sieve with a mesh size of $0.1 \mathrm{~mm}$ and homogenized in a screw homogenizer to ensure an even distribution of the grains in the sand.

Table 2: Characteristics of the sands

\begin{tabular}{|c|c|c|c|}
\hline & $\begin{array}{c}\text { Bulk density } \\
\left(\mathrm{g} / \mathrm{cm}^{3}\right)\end{array}$ & $\begin{array}{c}\text { Specific surface } \\
\left(\mathrm{cm}^{2} / \mathrm{g}\right)\end{array}$ & $\begin{array}{c}\text { Grinding time } \\
(\mathrm{min})\end{array}$ \\
\hline \multirow{2}{*}{$\begin{array}{c}\text { Quartz } \\
\text { sand 1 }\end{array}$} & \multirow{2}{*}{2.71} & 1130 & 23 \\
\hline \multirow{2}{*}{$\begin{array}{c}\text { Quartz } \\
\text { sand 2 }\end{array}$} & \multirow{2}{*}{2.73} & 2370 & 49 \\
\cline { 3 - 4 } & & 3640 & 65 \\
\cline { 3 - 4 } & & 1010 & 16 \\
\cline { 3 - 4 } & & 3540 & 36 \\
\hline
\end{tabular}

Figure 1 shows granulometric curves of the sands of three different fineness values of grinding and before grinding.

\subsection{Manufacture of samples}

The treated sand was homogenized with unslaked lime in the exact proportion to reach molar proportions of $\mathrm{C} / \mathrm{S}$ equal to 0.73 and 1.00 . Homogenization was carried out in a rotary homogenizer at $120 \mathrm{~min}^{-1}$. The time of the homogenization was $30 \mathrm{~min}$. The mix prepared in the above-mentioned way was mixed with water to the consistency of a liquid paste. The water was added into the mix gradually and by smaller portions to ensure safety during slaking of the contained lime. The water ratio of the mix (w), i.e., the proportion of water to complete amount of dry mix, was from $w=0.57$ [-] to 0.71 [-]. Sands with a lower specific surface were mixed with $w=0.57$ [-]. On the other hand, sands with a higher specific surface were mixed with $\mathrm{s} w=0.71[-]$. The consistence was constant. The liquid paste was poured into forms with a size of $(20 \times 20 \times 100) \mathrm{mm}$. After at least $24 \mathrm{~h}$, samples were taken out of the forms. The samples were dried in the laboratory environment $\left(23^{\circ} \mathrm{C}\right.$ $\pm 3{ }^{\circ} \mathrm{C}, 50 \%$ relative humidity) for $24 \mathrm{~h}$ and then placed in a drying chamber at a temperature of $40{ }^{\circ} \mathrm{C}$ for $24 \mathrm{~h}$. In total, 36 sets of samples were made. 


\subsection{Hydrothermal treatment}

The conditions of the hydrothermal reaction were ensured by means of laboratory autoclaving capsules. The steel capsules have PTFE inserts with a volume of $250 \mathrm{~mL}$. An inert distance pad was put into this insert to separate the tested sample from the surface of water needed for the hydrothermal reaction. The amount of autoclaving water corresponded to $15 \%$ of the working volume of the PTFE insert. The samples were placed on the pads. The autoclaving capsules were enclosed by tightening a double thread of the steel case. The capsules were placed in a drying chamber, where they stayed for the time of the hydrothermal treatment $(4,8$ and 16) h at a temperature of $190{ }^{\circ} \mathrm{C}$. In total, 18 different conditions for the formation of tobermorite were simulated ( 3 fineness of sand, 3 lengths of autoclaving and 2 molar proportions of $\mathrm{C} / \mathrm{S}$ ).

\subsection{Determination of the physical-mechanical proper- ties of the samples}

The bulk density and compressive strength of autoclaved samples were determined in accordance with EN $196-1{ }^{17}$ and EN $12390-7 .{ }^{18}$ The tests were carried out on dried samples.

\subsection{Treatment of the samples for the detection of tober- morite}

The cores of the samples were ground in a vibration grinder down to a maximum size of grain equal to $0.1 \mathrm{~mm}$. The powder was then ground in an isopropanol suspension in a micron grinder to the maximum size of grain equal to $0.2 \mathrm{~mm}$. The produced suspension was dried to a constant weight. The fine and dry powder was coated onto the carrier of the XRD machine and the XRD analysis was carried out with an Empyrean Panalytical machine.

The XRD analysis is based on the fact that the crystal lattice of each mineral has a specific distance between two parallel planes. This distance is called $d$. For a known wavelength $\lambda$ and measured angle $\theta$, it is possible to determine the specific distance $d$. This relationship is expressed with Bragg's equation (2). This is the basis for determining the crystallographic state of the examined material

$$
2 d \cdot \sin \theta=n \lambda
$$

\section{RESULTS AND DISCUSSION}

\subsection{Influence of the specific surface of sand on the bulk density of the composite material}

The values of the bulk density of the composites differed in the order of tens of $\mathrm{kg} / \mathrm{m}^{3}$. Such a difference seems to be negligible. However, even such small diffe- rences are a signal that some changes occurred in the microstructure of the composites.

The bulk density of all the samples (from both types of sand) showed a decreasing tendency as the value of the specific surface increased (Figure 2). This slight decrease was evident for both molar proportions C/S $(0.73$ and 1.0). The slight decrease of the bulk density has two reasons. First, the sand was homogenized after grinding, which caused considerable bulking. This bulking was more considerable for the finer sands. Therefore, it is probable that smaller grains of fine sand caught, during homogenization, more pores, which were then carried into the mix during the manufacture of the samples. Second, as mentioned above, the reactivity of the quartz grains grows with the increasing specific surface. Thanks

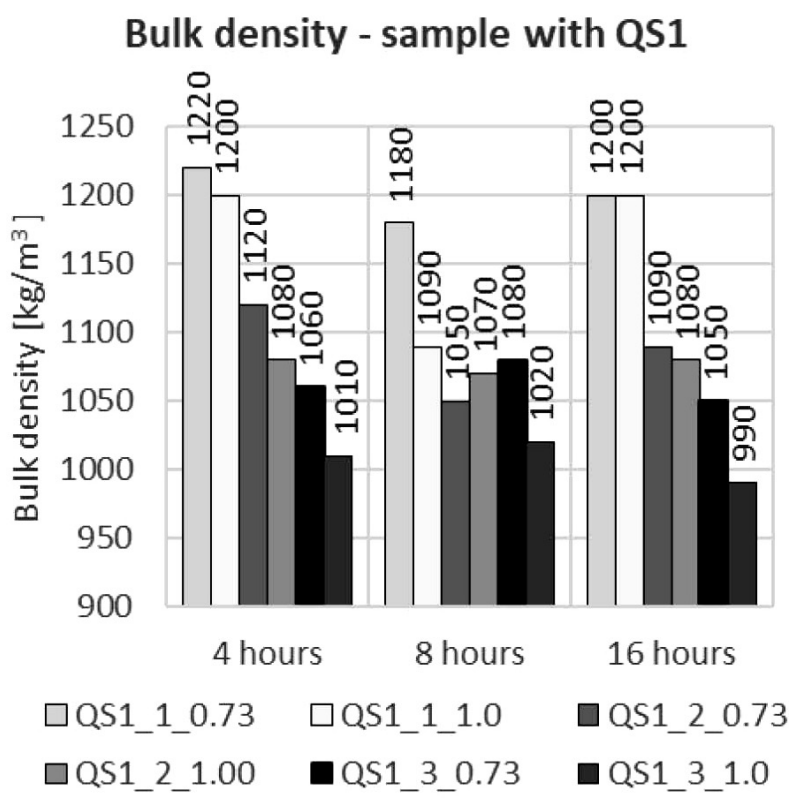

\section{Bulk density - sample with QS2}

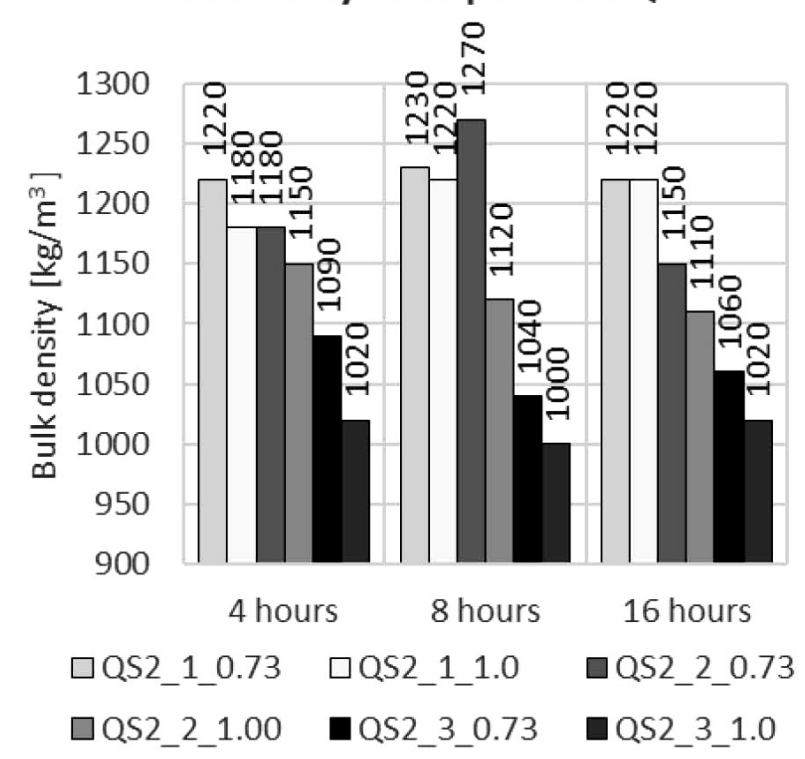

Figure 2: Bulk density QS1 and QS2 
to finer sand in the composite, the reactions of $\mathrm{SiO}_{2}$ and $\mathrm{CaO}$ were probably more profound. The resulting $\mathrm{CSH}$ phases show a lower bulk density, which implies a smaller reduction in the overall bulk density of the composite.

\subsection{Influence of the specific surface of the sand on the compressive strength of the composite}

The influence of the fineness of the sand on the compressive strength of the samples is more apparent than that observed with the bulk density.

The compressive strength of the samples showed an increasing trend with the increasing specific surface of the sand and the length of the autoclaving, as expected.

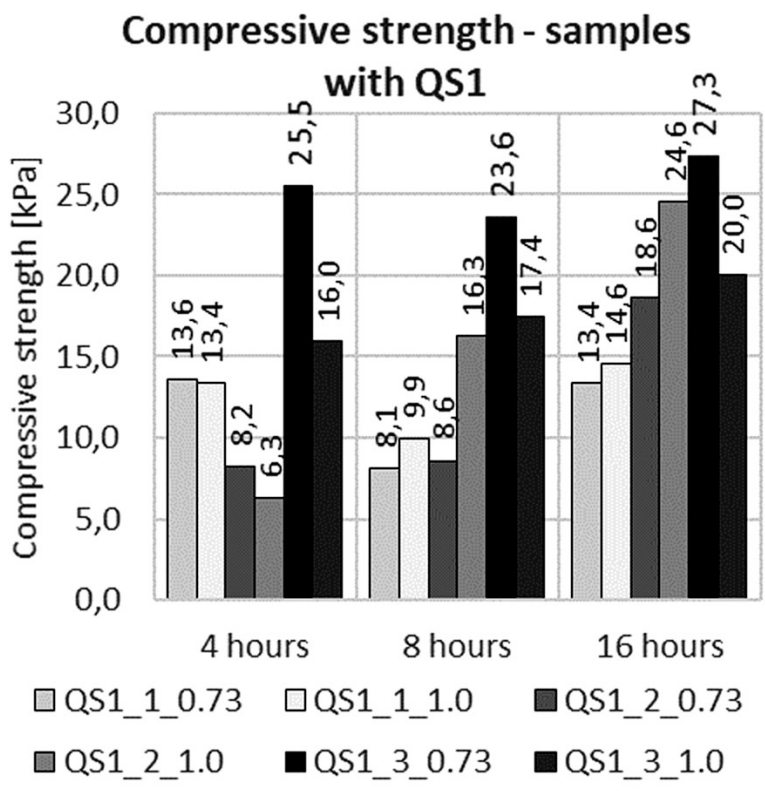

\section{Compressive strength - samples with QS2}

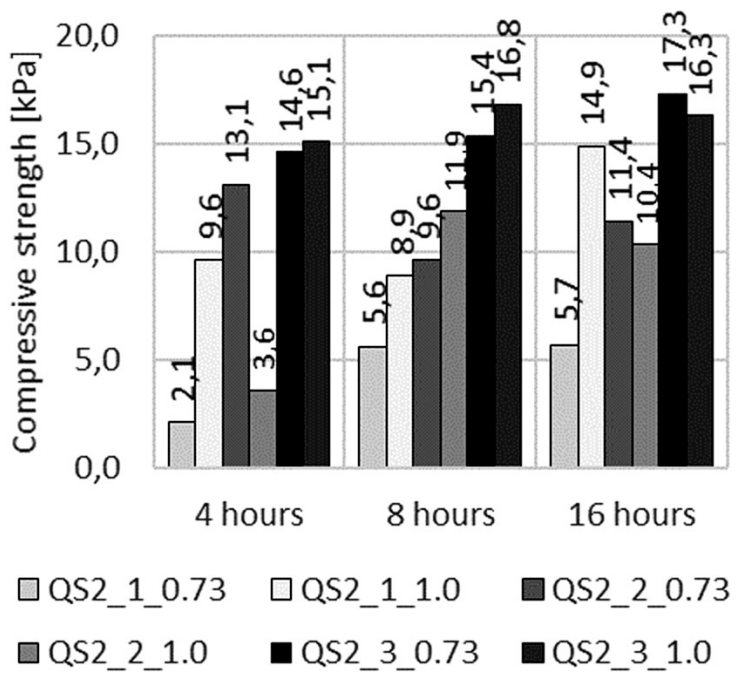

Figure 3: Influence of specific surface on the compressive strength QS1 and QS2
The increase is significant, especially for samples with a specific surface of around $2300 \mathrm{~cm}^{2} / \mathrm{g}$. On the other hand, a slighter increase was observed with the samples made from sand with a specific surface of around $3500 \mathrm{~cm}^{2} / \mathrm{g}$. These samples showed a higher strength even after $4 \mathrm{~h}$ of autoclaving. This is caused by the higher reactivity of the finer sands. Samples made from sands with a specific surface of around $1100 \mathrm{~cm}^{2} / \mathrm{g}$ showed similar values of compressive strength also after autoclaving for (8 and 16) h. The exception was the sample Quartz Sand 2 (QS2) with the molar proportion $\mathrm{C} / \mathrm{S}$ 1.0, which showed similar values of compressive strength as the sands with higher fineness.

The molar proportion of $\mathrm{C} / \mathrm{S}$ influenced the compressive strength, too. It is interesting that this influence is different for both types of sand, and its correlation is not unambiguous. Usually, samples with a higher molar proportion C/S 1.0 show lower values of compressive strength, like Quartz Sand 1(QS1) with a specific surface $3640 \mathrm{~cm}^{2} / \mathrm{g}$ (Figure 3). It is caused by the high content of portlandite in the microstructure. Portlandite creates large hexagonal crystals, which permeate the composite. These crystals probably do not connect the grains of aggregate and do not fulfil the function of a binder.

\subsection{Microstructure - the detection of tobermorite}

XRD analysis detected three dominant materials in the tested samples. These are silica, portlandite and

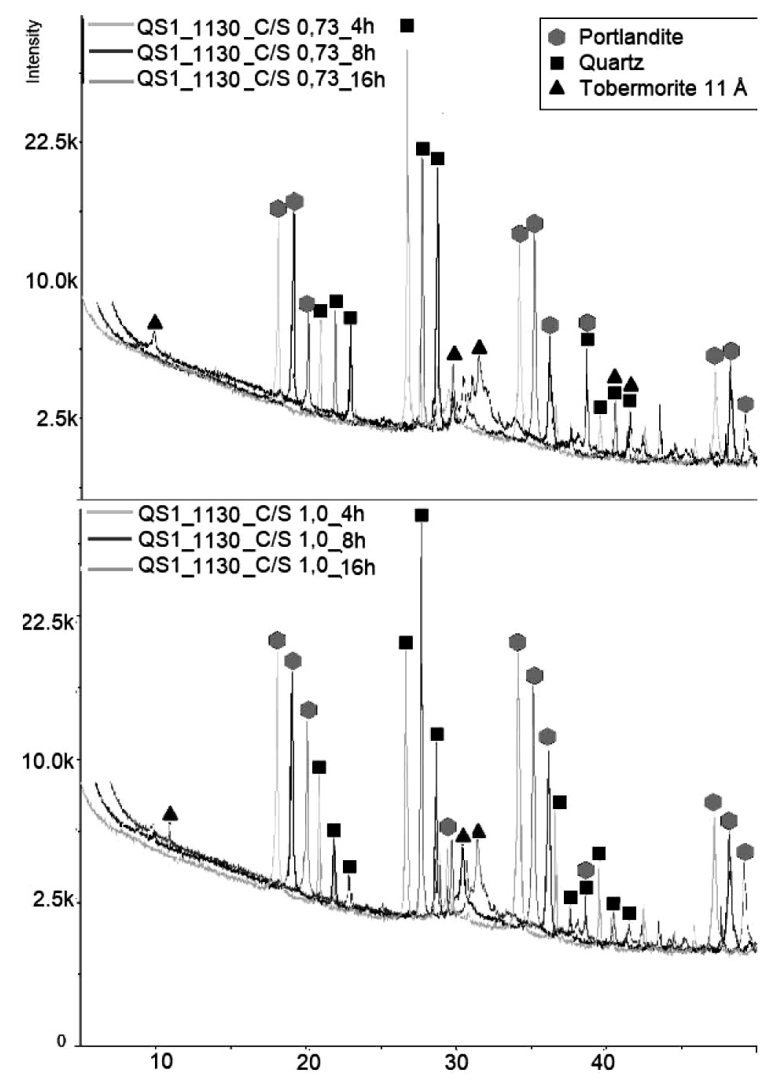

Figure 4: XRD diagram Quartz Sand 1, $1130 \mathrm{~cm}^{2} / \mathrm{g}$ 


\section{J. HÚŠTAVOVÁ et al.: INFLUENCE OF THE SPECIFIC AREA OF QUARTZ SAND ON THE CHARACTER ...}

tobermorite. The minerals are shown in the legend above the peaks. The XRD diagrams are completed so that the autoclaving times of $(4,8$ and 16$) \mathrm{h}$ are apparent. The curves are shifted by one degree to the right on the axis 2Theta. The XRD diagrams of the samples from QS1 and QS2 showed no significant differences; for this reason, the paper stated the XRD diagrams of the QS1 samples.

Samples made from sands with a fineness of around $1100 \mathrm{~cm}^{2} / \mathrm{g}$ with the molar proportion C/S 0.73 showed contents of the above-mentioned minerals in accordance with the XRD analysis (Figure 4). The 1,1 nm tobermorite was detected only after ( 8 and 16) h of autoclaving. The crystalline quartz showed a higher intensity of peaks at the time of $4 \mathrm{~h}$ of autoclaving. After longer autoclaving ( 8 and 16) h, the quartz was dissolved. This solubility is expressed by a decrease in the intensity of the peaks of quartz. At the same time, the intensity of the peaks of detected portlandite reduced, too. It is evident that after $4 \mathrm{~h}$ of autoclaving, the hydration of $\mathrm{CaO}$ and the formation of $\left(\mathrm{Ca}(\mathrm{OH})_{2}\right)$ occurred first. Then, after $8 \mathrm{~h}$ and $16 \mathrm{~h}$ of autoclaving, portlandite was dissolved, when $\mathrm{Ca}^{2+}$ ions reacted with dissolving quartz producing tobermorite. The sample with the molar proportion $\mathrm{C} / \mathrm{S}$ 1.0 showed a higher occurrence of portlandite; however, increasing of the molar proportion $\mathrm{C} / \mathrm{S}$ had no significant

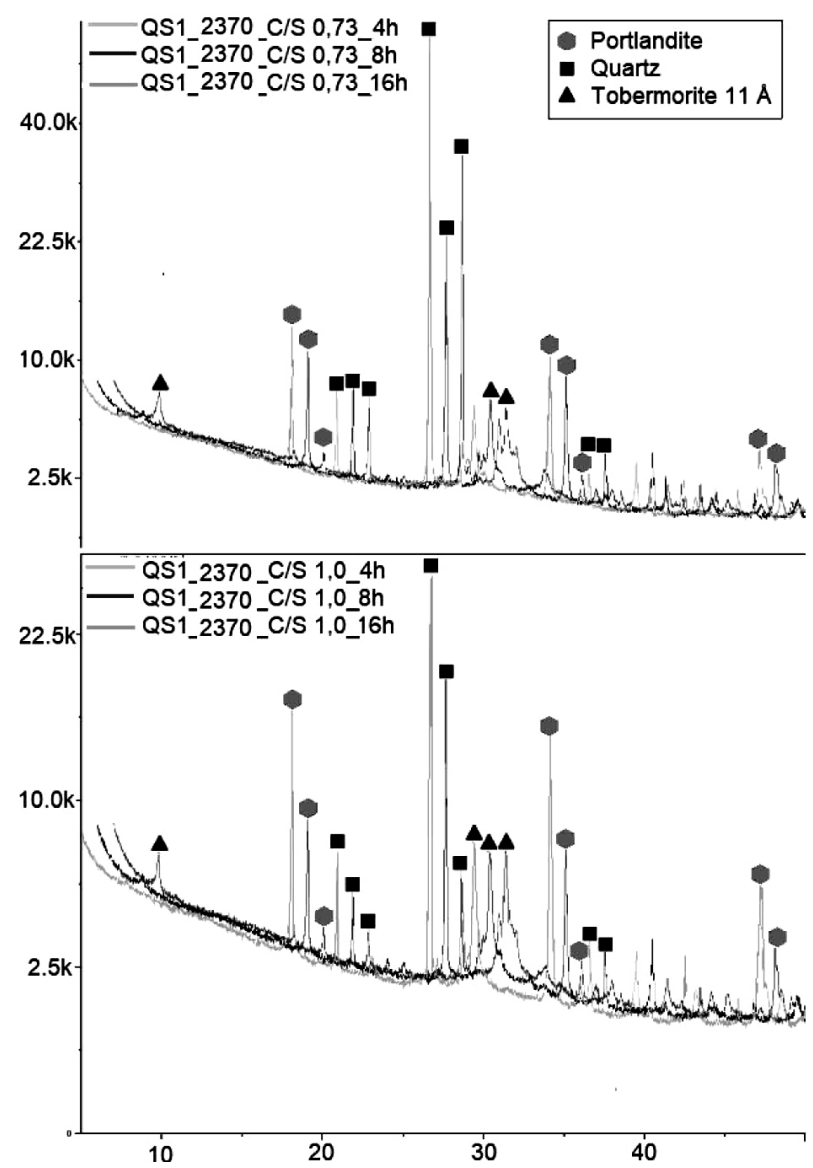

Figure 5: XRD diagram Quartz Sand 1, $2370 \mathrm{~cm}^{2} / \mathrm{g}$ influence on the formation of tobermorite, which showed the same intensity of peaks as the sample with C/S 0.73 . As regards the influence of $\mathrm{C} / \mathrm{S}$ on the solubility of quartz, it seems that a higher content of $\mathrm{CaO}$ in the sample with C/S 1.0 enabled a higher solubility. This fact can be explained by the sufficient amount of produced portlandite, which reacted with $\mathrm{Si}^{4+}$ ions, producing $\mathrm{CSH}$ phases.

The samples having sand with a specific surface of around $2300 \mathrm{~cm}^{2} / \mathrm{g}$ showed a higher intensity of tobermorite, in particular with the molar proportion C/S 1.0 (Figure 5). The increase of the peak of tobermorite was approximately $6 \%$. The solubility of the quartz was also higher, with a molar proportion C/S 1.0 Compared to the sand with a specific surface of $1130 \mathrm{~cm}^{2} / \mathrm{g}$, the samples showed a higher solubility of portlandite and quartz.

It is interesting that the samples with the finest sand, i.e., with a specific surface of $3600 \mathrm{~cm}^{2} / \mathrm{g}$, did not show the highest peaks of tobermorite according to the XRD. On the contrary, in the samples with the molar proportion C/S 1.0, tobermorite was detected only after $16 \mathrm{~h}$ of autoclaving, and only in low intensities. The high intensities of the peaks of portlandite and silica show that these were not consumed for the production of tobermorite. The contents of portlandite slowed the reaction of the fine grains on CSH phases. The same sample

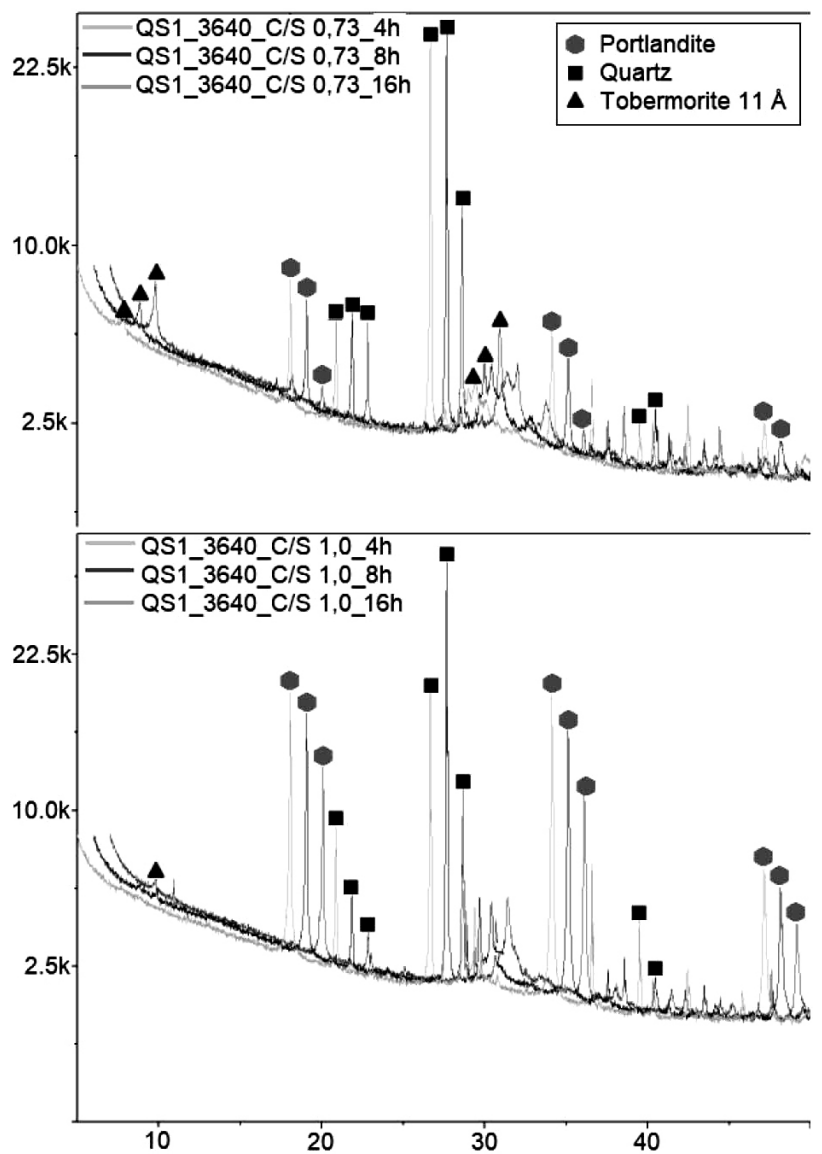

Figure 6: XRD diagram Quartz Sand 1, $3640 \mathrm{~cm}^{2} / \mathrm{g}$ 

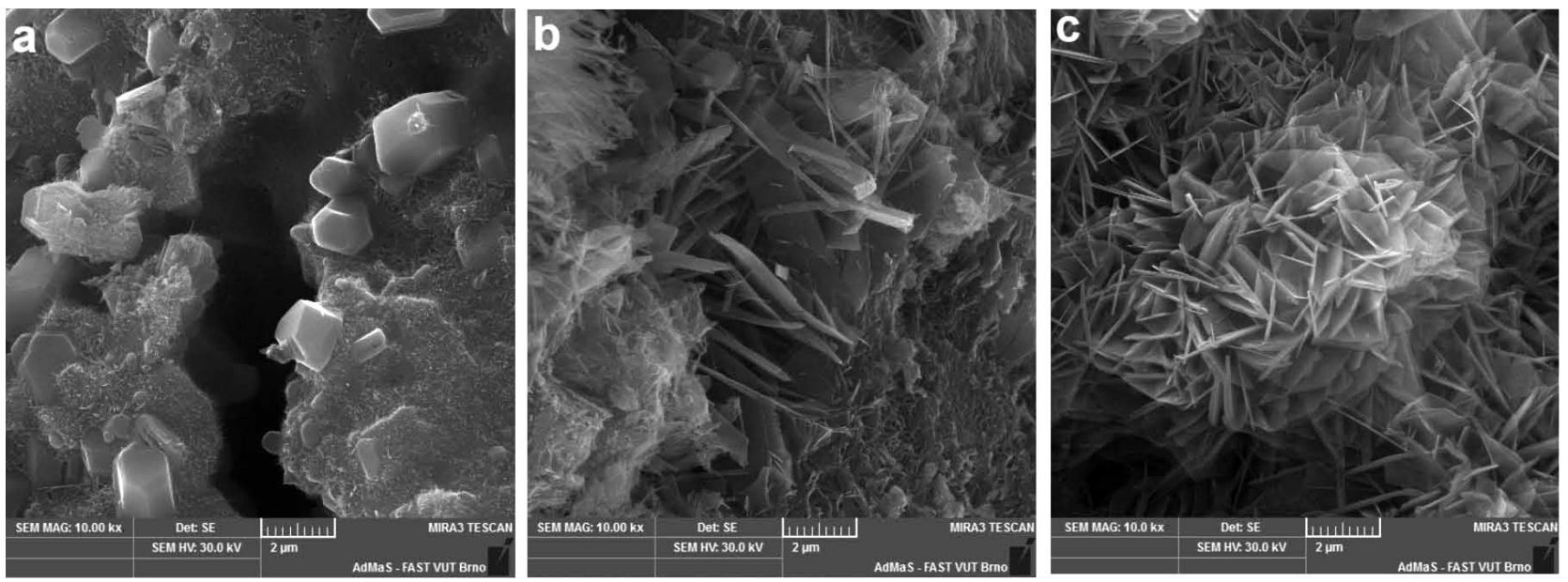

Figure 7: SEM images Quartz Sand 1, C/S 0,73, 4 h of autoclaving at $190{ }^{\circ} \mathrm{C}-$ a) $1130 \mathrm{~cm}^{2} / \mathrm{g}$, b) $\left.2370 \mathrm{~cm}^{2} / \mathrm{g}, \mathrm{c}\right) 3640 \mathrm{~cm} / \mathrm{g}$
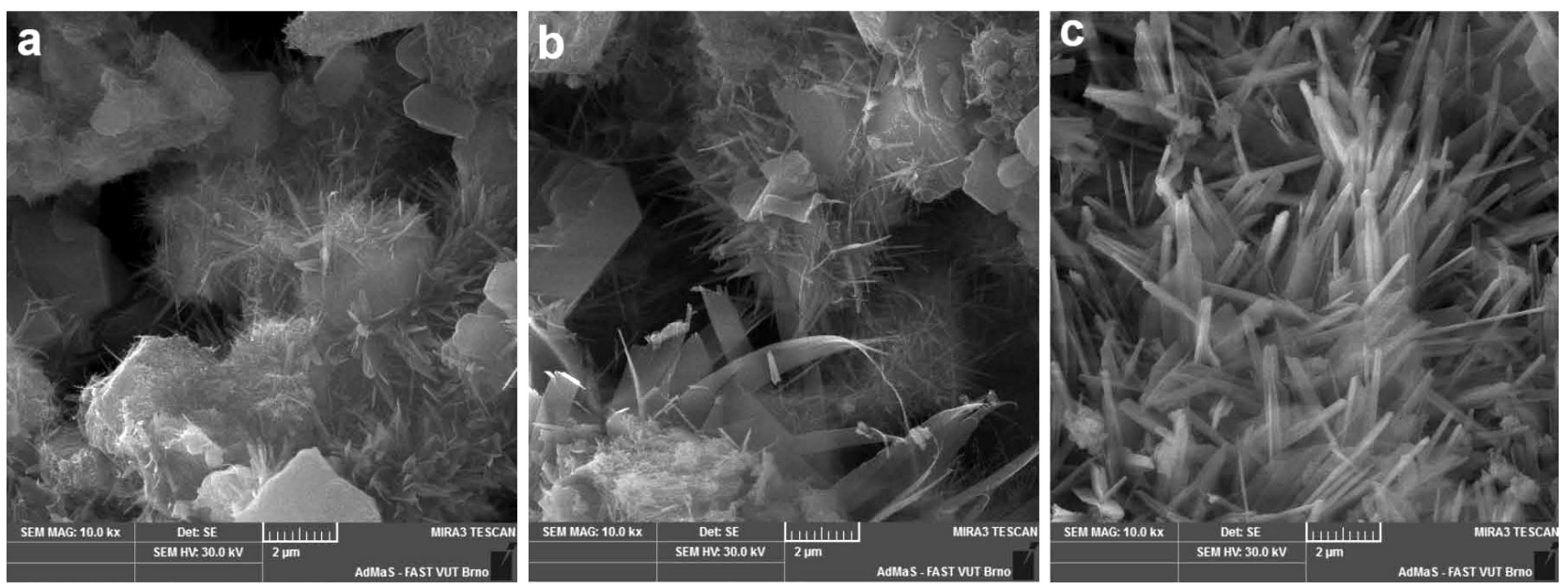

Figure 8: SEM images Quartz Sand 1, C/S 0,73, 16 h of autoclaving at $190{ }^{\circ} \mathrm{C}-$ a) $\left.\left.1130 \mathrm{~cm}^{2} / \mathrm{g}, \mathrm{b}\right) 2370 \mathrm{~cm}^{2} / \mathrm{g}, \mathrm{c}\right) 3640 \mathrm{~cm} / \mathrm{g}$

(Graph 3) showed a decrease of the compressive strength. Hartman states in his work that if the grains of quartz are smaller than $0.03 \mathrm{~mm}$, no crystallization of $1.1 \mathrm{~nm}$ tobermorite occurs. ${ }^{6}$ Sand with a fineness of $3600 \mathrm{~cm}^{2} / \mathrm{g}$ contained $50 \%$ of grains smaller than $0.03 \mathrm{~mm}$. It is probable that this content is one of the reasons for the reduction of the crystallization of tobermorite in the samples.

The sample with the molar proportion C/S 0.73 showed tobermorite of comparable intensity of peaks as the sample with the fineness of $2370 \mathrm{~cm}^{2} / \mathrm{g}$.

From the point of view of the content of tobermorite it could be said that the fineness of the sand should be sufficient at $2370 \mathrm{~cm}^{2} / \mathrm{g}$, and there is no need to grind to finer fractions. Even though the results of the compressive strength show an increase of the value with increasing fineness, this increase is only in the order of units of $\mathrm{kPa}$. The values of the compressive strength are generally low and serve as accompanying information for the study of the microstructure.

This paper presents SEM images of sample QS1. The images of QS1 and QS2 showed no significant difference. The selected times of autoclaving were $4 \mathrm{~h}$ and
$16 \mathrm{~h}$, as two extreme limits to show a visible difference in the crystallization of tobermorite.

The images show the dependence of tobermorite formation on the fineness of the grinding, even after $4 \mathrm{~h}$ of autoclaving (Figure 7a). Sample QS1 with a specific surface of $1130 \mathrm{~cm}^{2} / \mathrm{g}$ shows in the SEM image visible grains of quartz and crystals of portlandite. The grains of quartz are covered with CSH phases at early stages of crystallization; however, tobermorite is not visible here. At this time, the initial $\mathrm{CH}$ reacts first with the surfacehydrated Si groups only. When the specific surface of the quartz grain is higher, more portlandite is consumed. The level of demand of portlandite for the production of $\mathrm{CSH}$ phases is proportional to the area of the quartz grains. ${ }^{7,8,14}$

When the specific surface of sand was increased to $2370 \mathrm{~cm}^{2} / \mathrm{g}$ the tobermorite began to crystallize intensively into strong crystals in the form of laths (Figure 7b). These crystals were found mainly in pores and did not cover whole areas of the quartz crystals. Hexagonal crystals of portlandite were visible again. When the specific surface of the sand increased to $3640 \mathrm{~cm}^{2} / \mathrm{g}$, crystals of tobermorite were observed over the whole surface of the quartz grains (Figure 7c). Crystals of tobermorite 
showed a smaller and leaflet-like character. Tobermorite crystallized in this manner, with interlocked crystals, provides higher mechanical resistance and strength of the composite.

The images of the samples autoclaved for $16 \mathrm{~h}$ from the SEM analysis imply that the influence of autoclaving time on the crystallization of tobermorite is significant. When the quartz has a fineness of $1130 \mathrm{~cm}^{2} / \mathrm{g}$, thin, needle-shaped crystals of tobermorite are visible (Figure 8a), unlike after 4 h of autoclaving (Figure 7a). For a fineness of grinding equal to $2370 \mathrm{~cm}^{2} / \mathrm{g}$, the character of the tobermorite crystals changed from thin needles to wide sheets. These sheets are present together with subtle needles (Figure 8b). For a fineness of grinding equal to $3640 \mathrm{~cm}^{2} / \mathrm{g}$, a dense cover of tobermorite on the surface of the quartz crystals is visible again (Figure 8c). Compared to $4 \mathrm{~h}$ of autoclaving, the character of the tobermorite is that of long prisms here. Aggregates of $\mathrm{CSH}$ gel are apparent between the individual prisms.

\section{CONCLUSIONS}

The research into the influence of fineness of grinding on the manufacture of calcium silicate composites gave valuable results. As expected, the reactivity of the sand increased with increasing specific surface and the temperature of autoclaving. This was observable mainly with samples that had a molar proportion 0.73 , which showed the highest compressive strength.

- Influence of the fineness of the sand on the physicalmechanical properties

The bulk density increased with the increasing fineness of the grinding. The higher fineness of the grinding also brought an increasing tendency of the compressive strength across all versions of the hydrothermal conditions and mixing of the individual sands with unslaked lime.

- Influence of the fineness of the sand on the microstructure

As regards the microstructure, it was found that the level of the crystallization of tobermorite is unsatisfactory at a fineness of $1100 \mathrm{~cm}^{2} / \mathrm{g}$, and higher temperatures and a longer autoclaving time were required. When the fineness increased from $2300 \mathrm{~cm}^{2} / \mathrm{g}$ to 3600 $\mathrm{cm}^{2} / \mathrm{g}$, the increase of the crystallization of tobermorite was only negligible. It could be stated that grinding to $2300 \mathrm{~cm}^{2} / \mathrm{g}$ is sufficient from the point of view of the energetic and economic effectiveness of the technology.

- Influence of the molar proportion of $\mathrm{C} / \mathrm{S}$ and the autoclaving time

The research confirmed the assumption that the molar proportion $\mathrm{C} / \mathrm{S} 0.73$ is more suitable for the formation of tobermorite than $\mathrm{C} / \mathrm{S} 1.0$. It was also confirmed that 8 $\mathrm{h}$ of autoclaving at $180{ }^{\circ} \mathrm{C}$ is the optimal setting for the hydrothermal conditions. An increase of the autoclaving time to $16 \mathrm{~h}$ did not bring a significant increase of the compressive strength or the intensities of the peaks of tobermorite.

\section{- Projection of the further solution}

Specify the optimal value of the fineness of the grinding between $2300 \mathrm{~cm}^{2} / \mathrm{g}$ and $3600 \mathrm{~cm}^{2} / \mathrm{g}$ more precisely. Specify the limit of the molar proportion C/S for the formation of tobermorite and the solubility of quartz at various fineness values of the sand.

\section{Acknowledgment}

This paper has been worked out under the project no. LO1408 "AdMaS UP - Advanced Materials, Structures and Technologies", and under the project of the Czech Science Foundation (GACR) with the identification code GA17-14198S "Kinetics of silicon micro-structure creation in dependence on hydrothermal conditions and type of used materials".

\section{REFERENCES}

${ }^{1}$ R. A. L Wray, F. Sauro, An updated global review of solutional weathering processes and forms in quartz sandstones and quartzites. Earth-Science Reviews 171 (2017), 520-557, doi:10.1016/ j.earscirev.2017.06.008

${ }^{2}$ P. karásek, L. Š 'tavíková, J. Planeta, B. Hohnová, M. Roth, Solubility of fused silica in sub-and supercritical water: Estimation from a thermodynamic model, The Journal of Supercritical Fluids, 83 (2013), 72-77, doi:10.1016/j.supflu.2013.08.012

${ }^{3}$ M. Broekmans, A.T.M. Structural properties of quartz and their potential role for ASR. Materials Characterization, 53 (2004) 2-4, 129-140, doi:10.1016/j.matchar.2004.08.010

${ }^{4}$ G. B. Alexander, W. M. Heston, R. K. Iler, The Solubility of Amorphous Silica in Water. The Journal of Physical Chemistry, 58 (1954) 6, 453-455, doi:10.1021/j150516a002

${ }^{5}$ R. Zhang, X. Zhang, S. Hu, Dissolution kinetics of quartz in water at high temperatures across the critical state of water. The Journal of Supercritical Fluids, 100 (2015) 58-69, doi:10.1016/j.supflu. 2015.02.010

${ }^{6}$ A. Hartmann, Investigation of the crystallization behavior and the morphology of $11 \AA$ tobermorite as a function of the reactivity of the silica source and the ionic content of the hydrothermal solution (dissertation), University of Hannover, Department of Earth Sciences and Geography, 2004

${ }^{7}$ D. S. Klimesch, A. Ray, Effects of quartz particle size and kaolin on hydrogarnet formation during autoclaving, Cement and Concrete Research, 28 (1998) 9, 1317-1323, doi:10.1016/S00088846(98)00111-2

${ }^{8}$ D. S. Klimesch, A. Ray. Effects of quartz particle size on hydrogarnet formation during autoclaving at $180{ }^{\circ} \mathrm{C}$ in the $\mathrm{CaO}-\mathrm{Al}_{2} \mathrm{O}_{3}-\mathrm{SiO}_{2}$ $\mathrm{H}_{2} \mathrm{O}$ system. Cement and Concrete Research, 28(9)(1998), 1309-1316, doi:10.1016/S0008-8846(98)00112-4

${ }^{9}$ A. Hartmann, J.-Ch. Buhl, K. Van Breugel, Structure and phase investigations on crystallization of $11 \AA$ tobermorite in lime sand pellets. Cement and Concrete Research, 37 (2007) 1, 21-3, doi:10.1016/j.cemconres.2006.09.007

${ }^{10}$ J. Kikuma, M. Tsunashima, T. Ishikawa, S. Matsuno, A. Ogawa, K. Matsui, M. Sato, Effects of quartz particle size and water-to-solid ratio on hydrothermal synthesis of tobermorite studied by in-situ time-resolved X-ray diffraction. Journal of Solid State Chemistry, 184 (2011) 8, 2066-2074, doi:10.1016/j.jssc.2011.05.061.

${ }^{11}$ S. Wang, X. Peng, L.Tang, Lu Zeng, C. Lan. Influence of inorganic admixtures on the $11 \AA$-tobermorite formation prepared from steel 


\section{J. HÚŠTAVOVÁ et al.: INFLUENCE OF THE SPECIFIC AREA OF QUARTZ SAND ON THE CHARACTER ...}

slags: XRD and FTIR analysis, Construction and Building Materials, 60 (2014), 42-47, doi:10.1016/j.conbuildmat.2014.03.002

${ }^{12}$ P. Walczak, P. Szymański, A. Różycka, Autoclaved Aerated Concrete based on Fly Ash in Density $350 \mathrm{~kg} / \mathrm{m}^{3}$ as an Environmentally Friendly Material for Energy - Efficient Constructions. Procedia Engineering, 122 (2015), 39-46, doi:10.1016/j.proeng.2015.10.005.

${ }^{13}$ H. Youssef, D. Ibrahim, S. Komarneni, K. J. D. Mackenzie, Synthesis of $11 \AA$ Al-substituted tobermorite from trachyte rock by hydrothermal treatment. Ceramics International, 36 (2010) 1, 203-209, doi:10.1016/j.ceramint.2009.07.004

${ }^{14} \mathrm{~N}$. Isu, H. Ishida, T. Mitsuda, Influence of quartz particle size on the chemical and mechanical properties of autoclaved aerated concrete
(I) tobermorite formation, Cement and Concrete Research, 25 (1995) 2, 243-248, doi:10.1016/0008-8846(95)00003-8

${ }^{15} \mathrm{~T}$. Mitsuda, Influence of starting materials on the hydrothermal reaction in the $\mathrm{CaO}-\mathrm{SiO} 2-\mathrm{H} 2 \mathrm{O}$ system. The Journal of the Japanese Association of Mineralogists, 77, (1982), 317-329

${ }^{16}$ EN 459-1 ed 3:2015 - Building lime, Definitions, specifications and conformity criteria, European Committee for Standardization, Brussels

${ }^{17}$ EN 196-1:2016 - Methods of testing cement, determination of strenght, European Committee for Standardization, Brussels

${ }^{18}$ EN 12390-7:2009 - Testing hardened concrete, Density of hardened concrete, European Committee for Standardization, Brussels 